\title{
Tıp Öğrencilerinin İstatistik ve Bilimsel Araştırmaya Yönelik Kaygı ve Tutumları
}

\author{
Attitude and Anxiety of Medical Students Towards \\ Statistics and Scientific Research
}
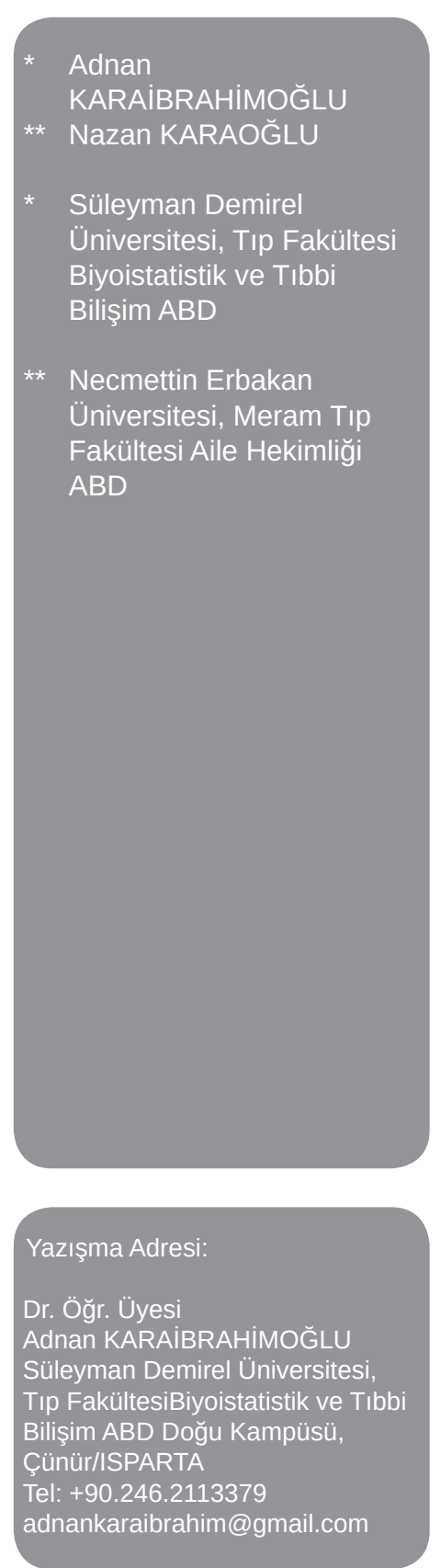

\section{Öz}

Amaç: Biyoistatistiğin önemi ve sağlık bilimlerindeki araştırma yöntemleri ile ilgili farkındalık bilinmekte, ancak genel olarak mezuniyet sonrası anlaşılmaktadır. Tıp fakültesi öğrencileri bu dersi eğitimlerinin ilk yıllarında almakta, bu nedenle gereksiz ve saçma bir ders olarak görülmektedir. Eğitimlerinin altıncı yılında kliniklerde stajyer öğrenci olana kadar istatistiği kullanmanın öneminin farkında değillerdir. Bu araştırmanın amacı, tıp fakültesi öğrencilerinin istatistiksel ve bilimsel araştırmalara yönelik tutum ve kaygı düzeylerini ve bunlara neden olan faktörleri belirlemektir. Gereç ve Yöntem: Bu çalışma, kesitsel tipte bir anket uygulaması olarak tasarlanmıştır. Etik Onay alındıktan sonra Meram Tıp Fakültesi ilk beş dönem öğrencileri içerisinden gönüllülük esasına göre seçilen 448 öğrenciye anket uygulanmıştır. Anket formu üç bölümden oluşmaktadır: Birincisi sosyo-demografik değişkenler, ikinci bölüm ise İstatistik Tutum Ölçeği (SAS) ve üçüncüsü Bilimsel Araştırma Yöntemleri Tutumu Ölçeği (SRMAS). Bulgular: Katılımcıların çoğunluğu birinci dönem öğrencisi ( $n=169, \% 37,7)$ ve yarısından çoğu kadın $(n=259, \% 58,3)$ idi. Dört öğrenciden üçü kendilerini ekonomik durum olarak orta derecede tanımladı ( $n=318, \%$ 72,6). Öğrencilerin yaklaşık \% 88'i $(n=393)$ tıp eğitimnini gönüllü olarak tercih etmişti. Her iki ölçekte cinsiyet, mezuniyet sonrası lise, tıp eğitimi tercihi, memleketi ve öğrencilerin ekonomik durum algısı açısından istatistiksel olarak bir farklılık yoktu. Bununla birlikte, Post Hoc testi, dönem-I öğrencilerinin $(99,13 \pm 18,17)$ istatistik kaygı düzeyinin dönem-Il öğrencilerinden $(89,67 \pm 19,84)$ anlamlı düzeyde yüksek olduğunu gösterdi. Sonuç: Tıp öğrencileri, kaygılarını azaltmak için bilimsel araştırma yöntemleri üzerine ders almalıdır. İstatistik dersi araştırma ve analiz becerilerine sahip olmak için yeterli olamamaktadır ve özellikle tıp eğitimi konsepti içerisinde klinik süreçte farklı dönemlerde de verilmelidir. Bu nedenle ders süresinin artırılması ve gerek istatistik dersi gerek bilimsel araştırma yöntemleri derslerinde tutumlarını olumlu hale getirmek adına bilgisayar laboratuvarı olanaklarının sağlanması ve pratik uygulamalar için süre ayrılması önerilmektedir.

Anahtar kelimeler: İstatistik, tıp eğitimi, bilimsel araştırma, kaygı, tıp öğrencisi

\section{Abstract}

Objective: The importance of biostatistics and the basic knowledge about research methods in the health sciences are known but generally, it was understood after graduation. The students of Medical Schools take biostatisti- 
cs courses in first years of their education. Therefore it can be thought as an unnecessary and ridiculous course. They are not aware of the importance besides do not utilize statistics until they become intern student in clinics in their sixth year. The purpose of this study was to determine the attitudes and anxiety levels of medical students towards statistics and scientific research and the factors contributing them. Materials and Methods: This is a cross-sectional study. We applied a questionnaire to the randomly selected 448 students on voluntary basis after an ethics approval. The questionnaire form has three parts: first part is about socio demographic variables, second part, consists of Statistics Attitude Scale (SAS) and third part is Scientific Research Methods Attitude Scale (SRMAS). Results: The majority of participants were first grade students $(n=169,37.7 \%)$ and more than half of them were females $(n=259,58.3 \%)$. Three of four students defined themselves as in moderate economic status ( $n=318,72.6 \%)$. Nearly $88 \%$ of the students $(n=393)$ have preferred the medical education voluntarily. There were no statistical difference in both scales in respect to gender, graduated high school, medical education preference, hometown and economic status perception of students. However, Post Hoc test showed that SAS score of first grade students (99.13 \pm 18.17$)$ is significantly higher than second gra-

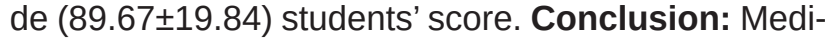
cal students should take courses on scientific research methods to reduce their anxiety. Statistics courses are not enough to have research and analysis skills and it should be given in different grades, especially at the beginning of clinical years of medical education. Therefore, we suggest that the duration of biostatistics course should be increased including the knowledge of research methods and computer lab facilities to gain practice in analyses.

Keywords: Statistics, Medical Education, Scientific Research, Anxiety, Medical students

\section{Giriş}

Son yıllarda, teknoloji geliştikçe istatistiksel analiz yöntemlerinin de yaşamın her alanında kullanıldığı görülmektedir. Sağlık alanı da istatistik gerektiren en yaygın alanlardan birisidir. Bu nedenle tıp sektöründe istatistik eğitimine özel bir önem verilir. Tıp, diş hekimliği, eczacılık, veterinerlik veya sağlık ile ilgili diğer bölümlerde öğrenim gören her öğrenci fakülte yıllarında biyoistatistik dersini alır. İstatistik ve olasılık kavramlarının anlaşılması, klinik yönergelerin değerlendirilmesinde, test sonuçlarının yorumlanmasında, grup karşılaştırmaları veya daha iyi bir tedavi yönteminin etkisinin belirlenmesinde yardımcı olacaktır (1). Bilimsel araştırmaların planlanması istatistik biliminin temel konularından birisidir. Araştırma çoğu zaman sadece olaylara bakma, bilgi ve veri toplama gibi değişik şekillerde tanımlanmaktadır. Genel anlamıyla araştırma, insanlığın yararına yönelik olma, bireyin ve toplumun karşılaştığı problemleri çözme gibi amaçlar için girişilen eylemlerdir. Bilimsel araştırma ise belli bir takım amaçlarla ve sistemli süreçler yolu ile veri toplama ve toplanan verilerin analizi olarak tanımlanabilmektedir. Bilimsel araştırma yapma yeterliliğini kazanabilmek, elbette ki belli bir eğitimden geçmeyi gerekli kılmaktadır. Araştırma eğitimi, araştırma yapabilmek ya da yapılan araştırmalardan etkin bir şekilde yararlanabilmek için gerekli olan bilgi ve beceri ile bilimsel tutum ve davranışların kazandırılmasını amaçlayan bir eğitim olarak tanımlanabilir (2).

\section{Tutum ve Kaygı}

Tutum, psikolojide bir kişiden veya bir olaydan hoşlanma veya hoşlanmama duygusu olarak tanımlanır. Tutum, davranıştan farklıdır ve bir şekilde duygular ve düşünceler ile bağlantılıdır. Tutum genel olarak üç bölümden oluşur: Etkisel (affective), davranışsal (behavioral) ve bilişsel (cognitive). Kaygı ise her insanın belli zamanlarda hissettiği normal bir duygudur. Çoğu insan herhangi bir sorunla karşılaştığında, bir sınavda veya önemli bir karar verirken kendisini kaygılı veya huzursuz hisseder (3-4). Eğitim bilimlerinde, herhangi bir öğrenme sürecinde az düzeyde kaygı motivasyonu tetiklemesi açısından yararlı kabul edilmektedir. Ancak kişi, istenilen düzeyin üzerinde bir kaygıya sahipse daha fazla oranda endişe ve korku içeren bu durum kaygı bozukluğu olarak adlandırılır (5-7). Kaygı bozukluğu, kişinin gündelik yaşam aktivitelerini bozan bir sıkıntıya sebep olur. Kaygı bozukluğunun görülme çeşidine göre bazı belirtileri vardır: korku veya panik durumu, el veya ayaklarda terleme, ağız kuruması, kalp çarpıntısı veya kesik nefes alma gibi. Bu tür belirtiler okul yıllarında birçok öğrencide görülmektedir. Çünkü kaygı öğrenme ile ilgilidir ve genellikle öğrenciler zor olduğunu düşündükleri bir konuyu öğrenirken kaygı hissederler (8). İstatistik de, matematik gibi, özellikle sosyal bölüm öğrencileri tarafından zor derslerden birisi olarak düşünülmektedir. Çünkü istatistik, sayısal beceri gerektirmekte ve birçok öğrenci niceliksel yöntemlere kendini yabancı görmekte veya onlarla baş et- 
mekten korkmaktadırlar. Bununla birlikte toplumda ve sosyal bilimlerde sayısal beceriler daha da önemli hale gelirken diğer yandan istatistik kaygısı öğrencilerin veriye karşı yapısal ve eleştirel bakış geliştirmelerine engel olan bir bariyer olmaktadır (7, 9-10).

Üniversite öğrencilerinin \%60-80 arası oranda rahatsız edecek derecede istatistik kaygısı yaşadıkları görülmektedir (11). Kaygı nedeniyle öğrenciler sıklıkla istatistik dersini ertelemekte ve hatta eğitim sürecinin son dönemlerine bırakmaktadırlar. Son yıllarda alınan bir istatistik dersi ise istenilen faydayı sağlamayacaktır. Yapılan çalışmaların çoğu istatistiğin içeriğinden çok meslek yaşamlarında istatistiği kullanmayacakları yönünde gelişen düşünceden dolayı kaygı yaşadıklarını göstermektedir. Benzer bulgular bir diğer çalışmada da ortaya çıkmıştır (12). Kaygının öğrencilerin algılama, yoğunlaşma ve istatistiksel kavramları çözümleme yeterlilikleri üzerindeki olumsuz etkisi nedeniyle öğrenme ve performans ikilisi bir araya gelememektedir. Hem düşük hem de çok yüksek kaygı düzeyinde performans daha zayıf olacaktır ve kayg düzeyi bu aşırı noktalardan uzaklaştıkça performans ta yavaş yavaş artacaktır. Kısacası öğrenciler istatistik sınavları nedeniyle sorun yaşamakta hatta bazen mezuniyetlerini ertelemektedirler. Birçok üniversitede istatistik dersi eğitim sürecinin bir parçası olarak zorunlu veya seçmeli olarak sunulmaktadır. Maalesef bu eğitim belli seviyede matematik becerisi gerektirmektedir. Bunun sonucunda öğrencilerde, özellikle de sosyal bilimler öğrencilerinde, istatistik dersine karşı bir ön yargı gelişmektedir (13). Tıp fakültesi öğrencilerinde istatistik dersine karşı bir bariyer oluşturma düzeyinin çok yüksek olmadığı ortaya konulmuştur. İstatistik dersi veya bilimsel araştırma yöntemleri derslerine yönelik tutum açısından yüksek puanlar elde edilmemiştir (9). İstatistik kaygısı hem öğrenciler hem de eğiticiler için bir sorundur. Öğrenciler açısından istatistik kaygısı kendi dersinde ve araştırmaya yönelik derslerde performans ile negatif yönlü bir ilişki oluşturur. Eğiticiler yönünden bakıldığında da istatistik dersleri genel bir sorun olarak görülmektedir (13). İstatistik eğitmeninin karşısına dört temel sorun çıkar: meslek yaşamlarında gereksiz gördükleri bir ders için motive etmek, istatistik öğrenme sürecinde genellikle karşılaşılan kaygı ile baş etmek, iyi ve kötü öğrencilerin hepsine birden verimli bir ders yapmak ve öğrenilen konuları zihinlere yerleştirmektir. Yöntemlerden birisi de temel istatistiğe yönelik kısa hikayelerdir. Bir eğitmen ve bir arkadaşı (herhangi bir meslekten olabilir) arasında geçen ve gündelik yaşantıda kullanılma- sı gereken basit istatistiksel kavramları yerleştirmeye çalışan senaryolar ile öğrencilerde bilginin daha kalıcı olması sağlanmış ve kaygı düzeyi azalmıştır (14). Eğiticinin öğrenciye yaklaşımı ile istatistik kaygısı arasında çok sıkı bir ilişki olduğu ortaya konulmuştur. Öğrencilerin sorularını çekinmeden sorabilmeleri için gösterilen olumlu yaklaşımlar psikolojik olarak rahatlama sağlamaktadır. Ayrıca eğiticinin duyarılığı, espri yapması veya etkili iletişim becerisinin yerinde kullanılması öğrencilerde istatistik kaygısını azaltmaktadır (15). Çağdaş toplumun temel özelliklerinden biri olarak görülen araştırma kültürü bilişsel, duyuşsal ve devinsel yeterlikleri ya da nitelikleri kapsamakta ve bireylere eğitimle kazandırılabileceği kabul edilmektedir. Ancak, araştırma bilgi ve becerisinin kazandırılması, bireyin araştırma yapabilmesi için temel bir koşul olmakla birlikte yeterli bir koşul değildir. Bireyin bu alana yönelik ilgisinin, sahip olduğu değerlerin ve dahası bu süreci kendisi için bir tehdit unsuru olarak görüp görmemesinin de onun araştırma yapmasında etkili olduğu görülmektedir (3). Yaşar çalışmasında araştırmacı eğitimin önemini ve yükseköğrenim kurumlarında son zamanlarda "bilimsel araştırma yöntemleri" derslerinin müfredatlara eklendiğini söylemektedir. Böylece öğrenciler gerçek hayatta karşılaşacakları sorunların üstesinden gelebileceklerdir. Ancak birçok araştırmacı bu konuda öğrencilerin, özellikle de sosyal bilimler öğrencilerinin araştırma yöntemleri dersine karşı olumsuz tutum gösterdiğini bulmuşlardır (16).

Kaygı, belli bir dereceye kadar kabul edilebilen normal bir durumdur. Ancak kişinin gündelik yaşantısını etkilemeye ve performansını olumsuz yönde etkilemeye başladığı andan itibaren bozukluk olarak kabul edilir. Eğitim içerisinde bu denli önemli yer tutan istatistik ile ilgili öğrenme kaygısının da tespit edilmesi ve buna göre önlemlerin alınması gerekmektedir. Gözlemlerimiz sonucunda fakültemiz öğrencilerinde biyoistatistik dersine karşı belirgin bir kaygı oluştuğu anlaşılmıştır. Bunun iki temel nedeni olabilir: istatistik dersinin verildiği dönem ve dersin içeriğinin veriliş biçimi.

Bu çalışma, bir tıp fakültesine ait öğrencilerin istatistik ve bilimsel araştırma yöntemlerine karşı tutumlarını ve kaygı düzeylerini ortaya koymak üzere hazırlanmıştır.

\section{Gereç ve Yöntem}

\section{Veri Toplama Araçları}

Çalışmada İstatistiğe yönelik tutum ölçeği (16) ve 
Bilimsel araştırma yöntemlerine yönelik tutum ölçeği (17) kullanılmıştır. Birinci ölçek Statistics Attitude Scale (SAS) adıyla, ikinci ölçek ise Scientific Research Methods Attitude Scale (SRMAS) adıyla anılacaktır. SAS ölçeği 33 madde ve beş alt boyuttan oluşmuştur. Alt boyutlar faktör analizi sonucu elde edilen aistatistiğin meslek yaşantısı ile ilişkisi, b-istatistik kaygısı-korkusu, c-istatistikten keyif alma, d-istatistiğin önemi ve e-algılanan istatistik şeklinde belirtilmiştir. Yaşar tarafından uygulanan anket çalışmasında ölçek puanı dokuzlu Likert tipi şeklinde 1-9 arası değer verilerek oluşturulmuştur. Ancak literatürde yaygın kullanımı olmaması nedeniyle bizim çalışmamızda beşli Likert şeklinde cevaplandırılmıştır (17). Ölçek puanının elde edilmesi amacıyla "kesinlikle katılmıyorum=1" den "kesinlikle katılıyorum=5"e kadar değer verilmiştir. Eksik bırakılan ifadelerin oranı düşük olduğundan $(\% 3,7)$ ortalama değer ile tamamlanmıştır. Toplam 19 madde ters değerlendirilmesi gerektiğinden puanlaması çevrilmiştir. SAS ölçek geliștirme aşamasında toplamda 58 istatistik tutum maddesi belirlenmiş, ancak faktör analizi sonucunda madde sayısı 33'e indirilmiştir. Elde edilen beş faktörün toplam varyans yükünün $\% 56,30$ 'unu açıkladığı görülmüş ve güvenirlik analizi sonucunda Cronbach's alpha değeri 0,927 olarak hesaplanmıştır. SRMAS ölçeği 20 madde ve dört alt boyuttan oluşmakta olup bunlar bilimsel araştırmanın önemi, bilişsel özgüven, ilgi ve meslek yaşantısı ile ilgisi olarak belirtilmiştir. Aynı şekilde ölçeğin orijinal uygulamasında 7'li Likert kullanılmasına karşın bizim çalışmamızda bütünlüğü bozmamak adına 5'li Likert düzeyinde "hiçbir zaman=1" den "her zaman=5"e kadar değerlendirilmiştir. Toplam beş madde olumsuz anlam içerdiğinden madde puanları ters çevrilerek veri girişi yapılmıştır. Ölçek geliştirme aşamasında ulaşılan bulgular ölçeğin geçerlik düzeyinin ve $\alpha=0,917$ olarak hesaplandığından iç tutarlılık düzeyinin yüksek olduğu anlaşılmıştır (16). Anket formu üç ana bölümden oluşmuştur. Birinci bölüm sosyo-demografik sorular: yaş, cinsiyet, memleket, mezun olunan lise tipi, yerleştirme puanı ve ekonomik durum. Bunlara ek olarak tıp fakültesini kendi isteğiyle tercih edip etmediği ve yeniden şansı olsa seçip seçmeme düşüncesi ile ilgili iki soru daha eklenmiştir. İkinci bölüm SAS ve üçüncü bölüm ise SRMAS ölçek ifadelerinden oluşmuştur.

\section{Evren-Örneklem}

Çalışmanın evrenini Necmettin Erbakan Üniversites Meram Tıp Fakültesi ilk beş dönem öğrencileri oluş- turmaktadır. Yapılması planlanan anket uygulaması için etik onayının alınmasından sonra çalışma başlatılmıștır. Tıp Fakülteleri 6 yıllık bir eğitim uygulamaktadır ve genel olarak iki aşamalıdır. ìlk üç yıl temel tıp eğitimleri ve mesleki beceri eğitimleri alan öğrenciler dördüncü yıldan itibaren klinik uygulamalar içerisinde rotasyona başlarlar. Dördüncü ve beșinci dönemlerde ağırıkı olarak sınıf dersleri de olmasına karşın altınCı dönemlerinde (intörn) tamamen hastane içerisinde ve yoğun bir klinik çalışma ortamına girerler. Altıncı dönem öğrencileri uygulama dışında bırakıldığından beş döneme ait yaklaşık 650 öğrenci bulunmaktadır. Klinik rotasyonu nedeniyle ilk beş döneme ait toplam 448 öğrenci ile anket uygulaması yapılmış ve yaklaşık \%69 gibi bir ulaşma oranına ulaşılmıştır.

\section{Verilerin Çözümlenmesi}

Çalışmanın tüm analizleri SPSS 20.0 paket programı kullanılarak yapılmıştır. Tanımlayıcı ölçüler için sayısal değişkenler (ortalama \pm ss) veya (medyan, min, maks) şeklinde, kategorik değişkenler ise frekans ve yüzde oranları şeklinde sunulmuştur. Sayısal değişkenlerin normal dağılıma uyup uymadığının anlaşılması için Kolmogorov-Smirnov testi kullanılmıştır. Grup karşılaştırmaları için iki grup durumunda student t-testi, çoklu grup durumunda tek tönlü varyans analizi kullanılmıştır. Post Hoc testi olarak Tukey HSD tercih edilmiştir. Ölçek bölümlerine ait güvenirlik analizi yapılarak Cronbah's alpha değerleri hesaplanmıştır. Geçerlik analizleri için Varimax döndürme yöntemi kullanılan Temel Bileşenler Faktör analizi uygulanmıştır. KMO ve Bartlett Küresellik değerleri hesaplamıştır. Kategorik değişkenler arasındaki ilişkinin tespit edilmesi amacıyla ki-kare analiz yöntemi kullanılmıştır. Anlamlı sonuçlar tablo veya ilgili grafikler ile görselleştirilmiştir. Analizlerin tamamında I. tip hata değeri \%5 kabul edilerek hipotez testlerinde karar vermek amacıyla $p<0,05$ değeri istatistiksel olarak anlamlı kabul edilmiştir.

\section{Bulgular}

Ankete katılan öğrencilerin \%41,7'si erkek ( $n=185)$, büyük çoğunluğu $(\% 82,0 ; n=355)$ sınavla girilen liselerden gelmiş ve \%68,2'si $(n=302)$ Konya dışından gelmişti. Anket uygulamasına $169(\% 37,7)$ dönem-I, 162 (\%36,2) dönem-II, 59 (\%13,2) dönem-III, $43(\% 9,6)$ dönem-IV ve $15(\% 3,3)$ dönem-V öğrencisi katıldı. Öğrencilerin büyük çoğunluğu $(\% 72,6 ; n=318)$ orta düzeyde ekonomik duruma sahipken \%25,1'i 
$(n=110)$ iyi düzeyde gelir seviyesine sahipti. Öğrencilerin \%88,7'si $(n=393)$ kendi isteği ile tıp fakültesini seçtiğini belirtirken \%60,9'u ( $n=265)$ yeniden sınava girse tekrar tıp fakültesini tercih edeceğini ifade etmişlerdi. SAS ölçeği içerisinde öğrencilerin en fazla katıldığı maddeler sırasıyla "istatistik dersinde sıkılıyorum" (\%60), "günlük yaşantımda istatistiğe intiyaç duymayacağımı düşünüyorum" (\%52) ve "istatistiksel kararların hayatta fazla yeri olduğunu düşünmüyorum" (\%50) olmuştu. Öğrencilerin en fazla katılmadığı maddeler ise "boş zamanlarımda istatistik ile ilgilenirim" (\%81), "istatistiksel problemler çözmekten hoşlanırım" (\%68) ve "İstatistik üniversitelerin bütün bölümlerinde zorunlu ders olarak konulmalıdır" (\%65) olmuştu. SRMAS ölçeği içerisinde öğrencilerin daha sıklıkla uyguladıklarını düşündükleri maddeler $\% 50$ civarında "araştırma odaklı düşünmenin hayatımda önemli bir yere sahip olduğunu düşünüyorum", "araştırma yöntemleri dersinde kazandığım becerilerin meslek yaşantımda faydalı olacağını düşünmüyorum" ve "bilimsel araştırma yöntemleri dersinde başarılı olacağımı düşünüyorum" ifadeleri olmuştu. Dersin ilgi çekici olması, derste başarılı olacaklarını düşünmeleri türünden ifadeleri hiç düşünmedikleri; gereksiz bir ders olduğu ile ilgili düşünceye \%48 civarında katıldıklarını belirtmişlerdi. Ölçek puanlarına ilișkin tanımlayıcı ölçüler Tablo.1'de sunuldu.

Her iki ölçek puan değerlerinin dağılımının normal dağılıma uyduğu görüldü (KS $z=1,132 ; p=0,154$ ve $K S$ $z=0,716 ; p=0,685)$. Bu nedenle parametrik testler kullanıldı.

SAS ölçeği için erkeklerin kadınlardan daha fazla kaygı puanına sahip olduğu görüldü. Ancak bu farklılık istatistiksel olarak anlamlı değildi $(t=1,853 ; p=0,065$ ve $t=1,698 ; p=0,090)$. Ayn şekilde, özel okuldan gelen öğrencilerin daha yüksek kaygıya sahip oldukları izlendi $(F(2,430)=0,371 ; p=0,690$ ve $F(2,430)=0,819$; $p=0,441)$. Ailesinin yanında yaşayan öğrenciler ile şehir dışından gelen öğrencilerin kaygı düzeyleri arasında fark bulunmadı $(t=0,784 ; p=0,433$ ve $t=-0,726$; $p=0,461)$.

SRMAS ölçeği için erkeklerin kadınlara göre, özel okuldan gelen öğrencilerin sınavla girilen liselerden gelen öğrencilere göre ve Konya dışından gelen öğrencilerin ailesi Konya'da bulunanlara göre daha fazla kaygı puanına sahip oldukları görüldü. Ancak bu farklar istatistiksel olarak anlamlı bulunmadı.

Birinci dönemden beşinci döneme kadar her iki ölçek puan ortalamaları Tablo.2'de sunuldu. En yüksek kaygı düzeyinin Dönem-ı öğrencilerine ait olduğu, diğer dönemlere ait ortalama değerlerinin birbirine yakın olduğu görüldü $(F(4,443)=5,76 ; p<0,001)$. Tukey HSD test sonuçlarına göre 1 . ve 2 . Dönem öğrencileri arasındaki farkın anlamlı olduğu $(p<0,001)$ anlaşıldı. Diğer dönemler arasındaki farklar anlamlı bulunmadı (Şekil.1).

\begin{tabular}{|c|c|c|c|c|c|c|}
\hline Değişken & Grup & & SAS & & SRMAS & \\
\hline & & $\mathbf{n}$ & Ort $\pm S S$ & p & Ort $\pm S S$ & $p$ \\
\hline \multirow[t]{2}{*}{ Cinsiyet } & Erkek & 185 & $96,03 \pm 19,21$ & 0,065 & $57,63 \pm 13,66$ & 0,090 \\
\hline & Kadın & 259 & $92,40 \pm 19,22$ & & $55,31 \pm 14,41$ & \\
\hline \multirow[t]{2}{*}{ Mezun olunan lise } & Sınavla girilen & 355 & $93,40 \pm 19,33$ & 0,690 & $55,86 \pm 14,14$ & 0,441 \\
\hline & Özel okul & 61 & $95,73 \pm 20,15$ & & $58,26 \pm 14,42$ & \\
\hline \multirow[t]{2}{*}{ Yaşadığı yer } & Konya & 141 & $94,82 \pm 17,32$ & 0,433 & $55,53 \pm 13,82$ & 0,468 \\
\hline & Konya dışı & 302 & $93,36 \pm 20,21$ & & $56,53 \pm 14,37$ & \\
\hline \multirow[t]{3}{*}{ Ekonomik durum } & İyi & 107 & $94,75 \pm 20,75$ & 0,663 & $56,16 \pm 14,33$ & 0,276 \\
\hline & Orta & 315 & $93,06 \pm 19,15$ & & $55,86 \pm 14,29$ & \\
\hline & Kötü & 10 & $96,10 \pm 19,54$ & & $63,30 \pm 12,01$ & \\
\hline
\end{tabular}

Ort= Ortalama, $\mathrm{SS}=$ Standart Sapma 
SRMAS ölçeği sonuçları SAS ile benzerlik gösterdi $(F=7,298 ; p<0,001)$. 1. ve 2. Dönem öğrencilerine ait puanlar arasında anlamlı fark tespit edildi $(p<0,001)$. Bu durum Şekil.2'de gösterildi.

Ekonomik durum düzeylerine ait ölçek puanları farklı bulunmadı $(F(2,435)=0,388 ; p S A S=0,663$ ve $F(2,435)=1,319$; pSRMAS $=0,276)$. Buna karşın, en düşük kaygı ortalamasının orta düzey ekonomik duruma sahip olanlara olduğu, gelir düzeyi iyi ve kötü olanlarda kaygı puanının daha yüksek olduğu anlaşıldı. Güvenirlik analizleri sonuçlarına göre SAS için Cronbach's alpha $=0,900$ ve SRMAS için Cronbach's

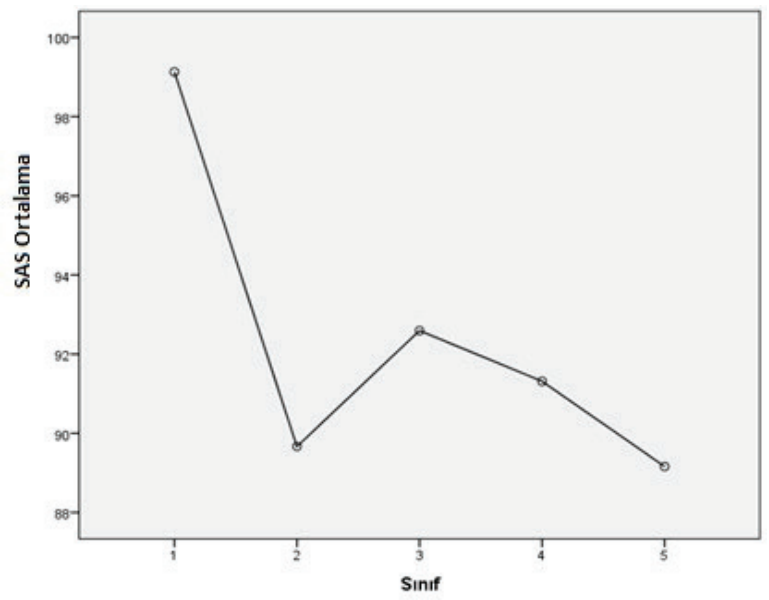

Şekil 1 Dönemlere göre SAS ortalama değerleri alpha $=0,905$ olarak birbirine yakın bulundu. Maddeler arasındaki korelasyonlar incelendiğinde en yüksek korelasyon katsayılarının istatistiğin meslek yaşantısındaki yeri ve öneminin olumsuz düşüncesi ile ilgili 8., 13. ve 24. maddelerine ait olduğu ve aralarındaki korelasyon değerlerinin \%60-\%65 arasında olduğu görüldü. SAS için genel madde puan ortalamasının $2,48 \pm 0,20$, SRMAS ölçeği içinse madde puanı orta-

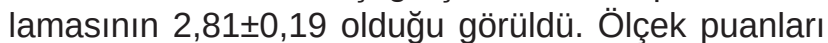
ve sınav puanı değişkenleri arasındaki ilişki incelendiğinde her iki ölçek puanı ile anlamlı korelasyon katsayıları elde edilmedi ( $r S A S=-0,035(p=0,491)$ ve rSRMAS $=-0,077(p=0,131))$. Geçerlik değerlerini elde

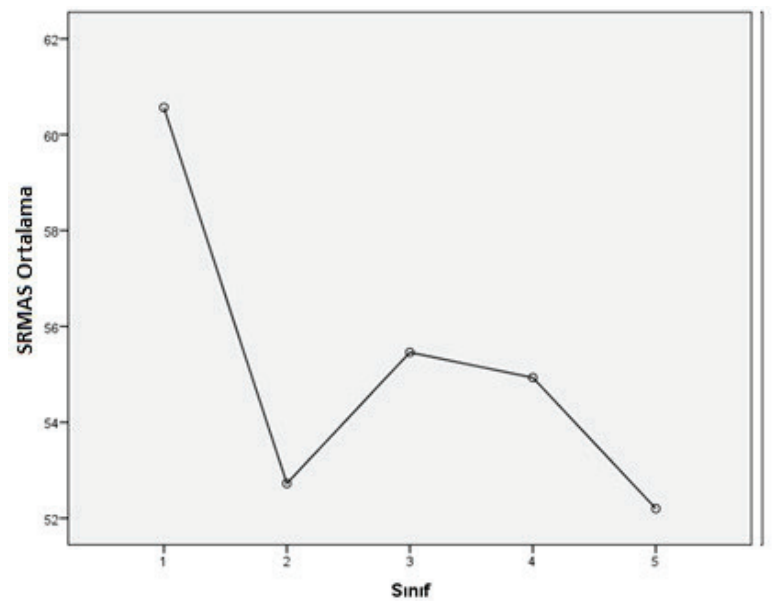

Şekil 2 Dönemlere göre SRMAS ortalama değerleri

\begin{tabular}{|c|c|c|c|c|c|c|c|}
\hline Ölçek & Dönem & $\mathbf{n}$ & Ort $\pm S S$ & Medyan & Min & Maks & $p$ \\
\hline \multirow[t]{5}{*}{ SAS } & Dönem-1* & 169 & $99,13 \pm 18,17$ & 99 & 47 & 145 & \multirow[t]{5}{*}{$<0,001$} \\
\hline & Dönem-2* & 162 & $89,67 \pm 19,84$ & 91,1 & 37 & 140 & \\
\hline & Dönem-3 & 59 & $92,59 \pm 18,36$ & 94 & 41 & 132 & \\
\hline & Dönem-4 & 43 & $91,31 \pm 20,14$ & 94,41 & 53 & 146 & \\
\hline & Dönem-5 & 15 & $89,16 \pm 14,43$ & 92 & 55 & 117 & \\
\hline \multirow[t]{5}{*}{ SRMAS } & Dönem-1* & 169 & $60,57 \pm 13,48$ & 60 & 20 & 96 & \multirow[t]{5}{*}{$<0,001$} \\
\hline & Dönem-2* & 162 & $52,72 \pm 14,56$ & 52,07 & 22 & 89 & \\
\hline & Dönem-3 & 59 & $55,46 \pm 12,01$ & 55 & 29 & 83 & \\
\hline & Dönem-4 & 43 & $54,93 \pm 14,59$ & 54 & 28 & 100 & \\
\hline & Dönem-5 & 15 & $52,20 \pm 11,15$ & 52 & 36 & 74 & \\
\hline
\end{tabular}




\begin{tabular}{|c|c|c|c|}
\hline & & SAS & SRMAS \\
\hline $\begin{array}{c}\text { Kaiser-Meyer-Olkin örneklem } \\
\text { yeterliliği testi }\end{array}$ & \multirow{3}{*}{ Ki-Kare } & 0,931 & 0,905 \\
\hline \multirow[t]{2}{*}{ Bartlett's Küresellik testi } & & 6283,575 & 4161,636 \\
\hline & & $p<0,001$ & $p<0,001$ \\
\hline
\end{tabular}

etmek amacıyla temel bileşenler analizine dayalı faktör analizi yapıldığında her iki ölçek için Tablo.3'te gösterilen değerler elde edildi. Elde edilen değerler önemli düzeyde anlamlı olup ( $p<0,001)$ verilen cevaplar faktör analizine uygundur.

SAS ölçeği için altı faktör elde edilmiş ve bu alt yüklerin döndürülmüş kareler toplamı kümülatif varyansın \%56,46'sını açıklamaktadır. SRMAS ölçeği içinse dört faktör elde edilmiş olup toplam varyansın \%62,05'ini açıklamaktadır. Alt boyutlara ait sayıların ölçeklerin orijinal çalışmasında elde edilen boyut sayılarında birer fazla olduğu bulunsa da açıklanan toplam varyans yüklerinin birbirine yakın olduğu anlaşıımıştır. SAS ölçeği için 5. ve 6. maddelerine ait, SRMAS ölçeği için 4. ve 5. maddelerine ait alt boyutların özdeğerlerinin birbirine yakın olması nedeniyle birleştirildiğinde ölçeklerin orijinalleri ile uyumlu olduğu görülmektedir.

\section{Tartışma ve Sonuç}

Bilimsel araştırmaların genellenebilmesi ve elde ediIen sonuçların bilimsel anlamda geçerli olabilmesi için istatistik ve önemli bir parçası olan bilimsel araştırma yöntemlerinin doğru olarak kullanılması gerekmektedir. Bu nedenle, sağlık ile ilgili yüksek öğrenim düzeyinde tüm öğrencilere biyoistatistik dersi verilmektedir. Öğrencilerin bu ders ile ilgili düşüncelerini çeşitli platformlarda dile getirmeleri nedeniyle son yıllarda istatistiğin öğrenciler için bir bariyer olup olmadığı düşüncesi ile araştırmalar yapılmış ve ölçekler geliştirilmiştir (9). Yapılan her çalışma sonucunda istatistiğin gereksiz bir ders olarak algılandığı ve eğitim süreçlerini olumsuz yönde etkileyen bir bariyer olduğu düşüncesi ortaya çıkmıştır (11-13). Onwuegbuzie ve Wilson, tarafından yapılan çalışmada cinsiyet, yaş ve etnik köken gibi demografik özelliklerin istatistik kaygısı üzerinde etkili olduğu gösterilmiştir. Ayrıca, yapısal eşitlik modellemesi analizine göre istatistik kaygısı ile başarı, araştırma kaygısı, çalışma alışkanlığı, ders yükü ve alınan istatistik ders sayısı arasında anlamlı ilişkiler olduğu gösterilmiştir (11). Farklı bir çalışmada ise 25 yaş altı öğrencilerin daha yaşı fazla öğrencilere göre, lisans öğrencilerinin lisansüstü öğrencilere göre ve işletme derslerindeki kaygı düzeyinin diğer derslere göre daha yüksek olduğunu; cinsiyet ve ırk özelliklerinin kaygı düzeyinde anlamlı etkiye sahip olmadığı gösterilmiştir (18). Bir eğitim fakültesinde 88 lisans öğrencisi ile yapılan çalışmada istatistik kaygısının ders performansını etkilemediği, ancak öğrencilerin öz yeterlilikleri ile istatistik kaygısı arasında orta düzeyde negatif yönlü bir korelasyon olduğu gösterilmiştir (19). İstatistik kaygısının azalmasına etki eden diğer bir faktörün ise dersi veren eğiticinin yakınlığı olduğu gösterilmiştir (14). Cherney ve Cooney, geliştirdikleri ölçek ile orta ölçekli bir üniversitenin lisans öğrencileri ile istatistiğe karşı düşük tutum ve öz yeterlilik düzeyine sahip öğrencilerin dikkatlice izlenmesi gerektiğini ifade etmişlerdir (20). İstatistik kaygı ölçeği (SAS) kullanılarak farklı iki ülkede yapılan çalışmada istatistik kaygısı ile matematiksel yetenek, öz yeterlilik ve istatistiğe karşı tutum arasında ters yönlü ilişki ortaya konulmuştur (12). Fen-Edebiyat Fakültesi mezunları ile yapılan Bilimsel Araştırma Yöntemleri kaygı düzeyi çalışmasında, kaygı düzeyinin demografik özellikler ile ilişkili olmadığı, ancak araştırma yöntemlerine dönük bir ders alma durumunun kaygı düzeyi üzerinde etkili olduğu gösterilmiştir (2). Yapılan çalışmaların çoğunluğunun sosyal bilimler ve az bir kısmının da fen bilimleri öğrencileri olduğu izlenmektedir. Tıp öğrencileri üzerinde yapılan çalışma sayısı oldukça azdır. Oysa istatistiğin en yoğun kullanıldığı yerlerden birisi sağlık sektörüdür. Beurze ve diğ. tarafından tıp fakültesi öğrencileri ile yapılan çalışmada STARS ölçeği kullanılmış ve öğrencilerin orta düzeyde bir kaygıya sahip oldukları hesaplanmıştır. Kadınlarda erkeklere göre daha yüksek kaygı düzeyi tespit edilmesine karşın yaş, kaygı üzerinde etkili bulunmamıştır (21-22). 
Diğer bir çalışmada ise tıp fakültesi öğrencilerinin tıbbi istatistik derslerini zor olarak algıladıkları, ancak yüksek düzeyde stres, korku veya kaygıya sahip olmadıkları gösterilmiştir (1).

Yaptığımız çalışmada literatürde belirtilen sonuçlara yakın bilgiler elde edilmiştir. Öğrencilerimizin orta düzey bir istatistik ve bilimsel araştırma yöntemlerine yönelik kaygıya sahip oldukları ortaya çıkmıştır. Birinci sınıf öğrencilerinde diğer sınıflara göre daha yüksek kaygı olduğu görülmüştür. Çalışma yapılan fakülte öğrencileri biyoistatistik dersini birinci yıl içerisinde almaktadırlar. Anket uygulanan dönemde konular, müfredat programının ortalarında bulunmaktaydı. Bu nedenle yüksek kaygı düzeyine sahip oldukları düşünülmektedir. Daha önceki çalışmalarda demografik bazı özelliklerin kaygı üzerinde etkili olduğu ortaya çıksa da bizim çalışmamızda hiçbir demografik özelliğin belirgin bir etkisi görülmemiştir. Literatür ile uyumlu olarak erkeklerin kaygı düzeyi biraz daha yüksek çıkmıştır. Aynı şekilde, ailesi ile birlikte yaşamanın veya başka bir ilden olup öğrenci evi, yurt gibi ortamlarda kalanlar gibi çalışma ortamları farklı olanların sahip olduğu kaygı düzeyleri arasında fark yoktur. Ekonomik düzeyin etkisi veya tıp fakültesini isteyerek seçme durumunun etkisi görülmemiştir. Her ne kadar yaş skalası çok geniş olmasa da ölçeklerden elde edilen kaygı puanları üzerinde anlamlı bir etkisinin olmadığı görülmektedir. İstatistik kaygısının lise düzeyindeki matematik performansı ile ters ilişkili olduğu saptanmıştır. Öğrenciler tıp fakültelerine üniversite giriş sınavından alınan sayısal puan türü ile yerleşmektedirler. Üst düzey sayısal beceriye sahip oldukları düşünülen öğrenciler yine de istatistiğin temelini oluşturan ortalama, varyans veya dağılım kavramlarının anlaşılması noktasında sıkıntı yaşamaktadırlar. Bununla ilgili olan 25. madde ("Matematik alt yapım iyi olduğundan dolayı istatistik beni kaygılandırmıyor") için \%62,7 oranında katılmadıklarını ifade etmeleri sayısal becerilerini yeterince kullanmak istemediklerinin bir göstergesidir. Oysa tıp fakültesi müfredatı yalnızca biyolojik bilimlerden oluşmamakta, belli oranda sayısal beceriler gerektiren dersler de bulunmaktadır (biyofizik, biyokimya, epidemiyoloji, nükleer tıp gibi). Öğrencilerin sınav giriş puanları ile ölçek puanları arasında korelasyon bulunmaması da bu durumu özetlemektedir.

Biyoistatistik dersinin müfredatı, süresi ve dersin verildiği dönem açısından tıp fakültelerinin farklı uygulamalara sahip olduğu görülmektedir. Genellikle ilk üç yıl içerisinde ve 25-30 saatlik bir süre içerisinde veril- mektedir. Bilimsel araştırma yöntemlerine ait herhangi ayrı bir ders müfredatı olmayıp genellikle biyoistatistik dersi içerisinde konuya az da olsa değinilmektedir. Mezuniyet sonrası eğitim programları içerisinde bazı enstitülerde bilimsel araştırma yöntemleri dersi veya bu içeriğe yakın dersler konulabilmektedir. Öğrenciler dördüncü yıldan itibaren klinik derslere başlayıp hastane içine girdikten sonra artık istatistik dersi ile olan bağları tamamen kopmaktadır. Ancak mezuniyet sonrası uzmanlık eğitiminde tez hazırlama veya klinik hocalarının isteği üzerine akademik yayın çalışmaları nedeniyle istatistiği tekrar hatırlamakta, ancak unutulan bilgiler nedeniyle bilgileri tazelemekte çoğu zaman başarısız olmaktadırlar. Oysa bu süreç içerisinde gerek deneysel araştırma yapmaları gerekse ilgilendikleri alan ile ilgili veri toplamaları gerektiğinden kaygı düzeylerinin arttığı izlenmektedir. Bu nedenle biyoistatistik eğitiminin mümkün olduğunca yıllara yayılması ve süresinin artırılması gerekmektedir. $\mathrm{Bi}$ yoistatistik dersinin müfredatı çalışmanın yapıldığı fakültede değiştirilerek dersin daha rahat anlaşılmasını sağlayacak ve kaygıları azaltacak bir hale getirilmeye çalışılmıştır. İstatistiğin teorik yönüne bakan tarafına daha az değinilerek öğrencilerin ileride karşılaşmaları muhtemel örnek çalışmalar üzerinde daha fazla durulmuştur. Sayısal beceri gerektiren işlem yoğunluğu bilgisinden çok analiz yöntemleri üzerinde düşünme ve yorum yapabilme becerilerine önem verilmiştir. Bu nedenle ikinci dönem öğrencilerinin üst dönemlere ait ortalamalara göre daha düš̈̌ kaygıya sahip olmaları açıklığa kavuşmaktadır. Tıp fakültelerinde gittikçe artan öğrenci sayısı nedeniyle uygulamaya yönelik eğitimler verilememektedir. Oysa gerçek veriler üzerinde istatistiksel analiz programları ile uygulama yapmak öğrencilerin motivasyonunu artıracaktır. Meslek yaşamları içerisinde yapacakları araştırmalar için bilgisayarda tablolama programlarına aşina olmaları fayda sağlayacaktır. İstatistik bilimsellik adına bir gerekliliktir. Tıp fakültesi mezuniyet yeterlilikleri içerisinde bilimsel düşünceye sahip hekimlerin olması sağlık alanında yapılacak gelişmeler adına faydalı olacaktır.

\section{Kaynaklar}

1. Hannigan A, Hegarty AC, McGrath D. Attitudes Towards Statistics of Graduate Entry Medical Students: The Role of Prior learning Experiences, BMC Medical Education. 2014;14(70), 1-7

2. Yılmaz K, Çokluk Ö. Fen-Edebiyat Fakültesi Mezunlarının Araştırma Kaygı Düzeyler, Abant İzzet Baysal Üniversitesi Dergisi. 2010; 10(1): 1-9 
3. Onwuegbuzie AJ, Daley CE. The relative contributions of examination-taking coping strategies and study coping stretegies on test anxiety: a concurrent analysis, Cognitive Theraphy and research. 1996; 20:287303.

4. Onwuegbuzie AJ, Daley CE. Perfectionism and statistics anxiety, Personality and Individual Differences. 1999; 26:1089-1102.

5. Onwuegbuzie AJ, DaRos D, Ryan J. The components of statistics anxiety: a phenomenological study, Focus on Learning Problems in Mathematics. 1997; 19(4): 11-35.

6. Onwuegbuzie AJ, Seaman M. The effect of time and anxiety on statistics achievement, Journal of Experimental Psychology. 1995; 63:115-124.

7. Zeidner, M. (1991) Statistics and mathematics anxiety in social science students-some interesting parallels, British Journal of Educational Psychology. 61: 319-328.

8. Onwuegbuzie AJ. Academic procrastination and statistics anxiety, Assessment\&Evaluation in $\mathrm{Hi}$ gher Education, 2004; 29(1): 3-19, DOI:10.1080/ 0260293042000160384

9. Slootmaeckers K, Kerremans B, Adriaensen J. Too Afraid to Learn: Attitudes towards Statistics as a Barrier to Learning Statistics and to Acquiring Quantitative Skills Politics. 2014; 34(2): 191-200.

10. Büyüköztürk Ş. Araştırmaya Yönelik Kaygı Ölçeğinin Geliştirilmesi, Eğitim Yönetimi. 1997; 3(4): 453-464. 11. Onwuegbuzie AJ, Wilson VA. Statistics Anxiety: Nature, etiology, antecedents, effects, and treatments-a comprehensive review of the literature, Teaching in Higher Education. 2003; 8(2): 195-209, DOI: 10.1080/1356251032000052447

12. Chiesi F, Primi C, Carmona J. Measuring Statistics Anxiety: Cross-Country Validity of the Statistical Anxiety Scale (SAS), Journal of Psychoeducational Assessment. 2011; 29: 559-569

13. Shah Abd Hamid H, Sulaiman M. Statistics Anxiety and Achievement in a Statistics Course among Psychology Students, International Journal of Behavioral Science. 2014; 9(1):55-6.

14. D'Andrea L, Waters C. Teaching Statistics Using Short Stories: Reducing Anxiety And Changing Attitudes, ICOTS6 Proceedings, 2002; Cape Town, SA

15. Williams AS. Statistics Anxiety and Instructor Immediacy, Journal of Statistics Education. 2010; 18(2), 1-18

16. Yaşar M. Bilimsel Araştırma Yöntemleri Dersine Yönelik Tutum Ölçeği Geliştirme Çalışması: Geçerlik ve Güvenirlik, Eğitim Bilimleri Araştırmaları Dergisi.
2014; 4(2): 109-129.

17. Yaşar M. İstatistiğe Yönelik Tutum Ölçeği: Geçerlilik ve Güvenirlik Çalışması, Pamukkale Üniversitesi Eğitim Fakültesi Dergisi, 2014; 36(2): 59-75

18. Earp M. Development and Validation of the Statistics Anxiety Measure (Doctoral Dissertation), 2007. [Online] Retrieved from: https://www.stat.auckland. ac.nz/ iase/publications/dissertations/07.Earp.Dissertation.pdf

19. Schneider WR. The Relationship between Statistics Self-Efficacy, Statistics Anxiety, and Performance in an Introductory Graduate Statistics Course [Graduate Dissertations], University of South Florida, USA, 2011. Retrieved From: http://scholarcommons.usf. edu/etd/3335

20. Cherney ID, Cooney RR. Predicting Student Performance In A Statistics Course Using The Mathematics And Statistics Perception Scale (MPSP), Transactions of the Nebraska Academy of Sciences and Affiliated Societies-Paper41, 2005; 30: 1-8

21. Beurze SM, Donders AR, Zielhuis GA, de Vegt F, Verbeek ALM. Statistics Anxiety: A Barrier for Education in Research Methodology for Medical Students, J of Int'I Medical Science Educators. 2013; 23(3): 377- 384 22. Teman DE. Factorial invariance of the statistical anxiety rating scale across sex and students' classification, Comprehensive Psychology.2013; 2(1): 1-11 